\title{
Diversity of different farmer and modern wheat varieties cultivated in contrasting organic farming conditions in western Europe and implications for European seed and variety legislation
}

\author{
Estelle Serpolay • Julie C. Dawson • Veronique Chable • \\ Edith Lammerts Van Bueren • Aart Osman • Silvio Pino • Donato Silveri • \\ Isabelle Goldringer
}

Received: 19 January 2011 / Accepted: 1 June 2011 / Published online: 17 July 2011

(C) Springer Science \& Business Media BV 2011

\begin{abstract}
The importance of genetic diversity in cultivated varieties for organic and low-input agriculture has attracted increasing attention in recent years, with a need to identify relevant sources of diversity and strategies for incorporating diversity in plant breeding
\end{abstract}

E. Serpolay $\cdot$ V. Chable

INRA SAD Paysage,

65 rue de St. Brieuc, CS 84215 ,

35042 Rennes, France

J. C. Dawson · I. Goldringer $(\bowtie)$

UMR de Génétique Végétale,

INRA-Univ Paris-Sud-CNRS-AgroParisTech,

Ferme du Moulon,

91190 Gif-sur-Yvette, France

e-mail: goldringer@moulon.inra.fr

E. L. Van Bueren · A. Osman

Louis Bolk Instituute,

Hoofdstraat 24,

3972 LA Driebergen, the Netherlands

S. Pino

IGSA Strampelli,

via Marconi, 1 ,

36045 Lonigo, Italy

D. Silveri

ARSSA Ufficio Operativo Territoriale di Sulmona,

Via Quintino Sella, 5,

67039 Sulmona, L'Aquila, Italy for organic systems. However, the regulatory system in many countries, particularly in the European Union, restricts the varieties available to farmers to those registered in an official catalogue, and most countries require varieties to go through official tests under conventional management, which has resulted in a lack of suitable varieties available to organic farmers. This study characterized a sample of wheat (Triticum aestivum L.) landraces, historic varieties and varietal mixtures currently of interest to organic farmers in a diverse range of organic conditions on farms in Italy, France and the Netherlands. These varieties were assessed for individual plant and spike characteristics and compared to modern registered wheat varieties grown under the same on-farm conditions. Significant differences in mean values were found among varieties for many plant and spike traits, as well as significant variety-by-environment interactions. There were often similar levels of intra-varietal variability between farmer and modern varieties, indicating that the strong selection for genetic homogeneity to meet regulatory criteria has little impact on the phenotypic variability of certain traits when assessed on-farm. Several farmer varieties had high values of traits related to productivity outside their region of origin, which underlines the need for experimentation with diverse types of varieties in order to find and develop appropriate varieties for organic systems. 
Keywords Conservation varieties $\cdot$ Farmer varieties . Genetic diversity · Phenotypic variability · Organic agriculture $\cdot$ Seed regulations

\section{Introduction}

Recent articles have identified the need for varieties specifically adapted to low-input and organic agriculture due to differences in key traits required in these systems and differences in farmer priorities among traits of importance (Ceccarelli and Grando 2007; Desclaux et al. 2008; Murphy et al. 2007; Wolfe et al. 2008). In addition to well-adapted varieties, the conservation of genetic diversity within varieties is also important to maintain the adaptive potential of these varieties. Farmers using organic or low-input practices look for more diverse varieties because they want these varieties to be able to evolve specific adaptation to their conditions and because genetic heterogeneity may buffer crop responses to unpredictable environmental conditions (Becker and Leon 1988; Ceccarelli et al. 2001; Finckh 2008). This buffering capacity is more important in low-input and organic systems because farmers are not able to standardize growing conditions with the use of synthetic inputs (Ceccarelli et al. 2001; Altieri 1999; Desclaux 2005; Finckh and Wolfe 2006; Wolfe 2000). While diverse varieties such as landraces, historic varieties and mixtures (referred to as farmer varieties hereafter, see Box 1) are currently of greater relevance in organic than in conventional agriculture (Almekinders and Jongerden 2002), the preservation of diversity is important for all agricultural systems due to changing climate conditions, which change both the types and levels of biotic and abiotic stress that crops face.

Interest in growing farmer varieties and conserving genetic diversity is growing in the organic farming community in Europe because of a lack of welladapted modern varieties, a recognition of the value of genetic diversity, a need to reduce off-farm inputs, a desire for more autonomy in terms of seed production and an increased market value of these varieties due to consumer recognition and demand for certain well-known varieties. Several groups of farmers in Europe, the Réseau Semences Paysans (in France), Red de Semillas (in Spain) and the Rete
Semi Rurali (in Italy) are actively engaged in testing farmer varieties and in some cases, selecting superior plants within existing landraces and historic varieties to use as new farmer varieties or in mixtures. These networks are very concerned with the loss of genetic diversity among modern varieties and the consolidation of the seed market and ensuing loss of farmer choice and control of the seed they plant. Similar initiatives exist in other European countries; the European Farm Seeds Opportunities project has identified 68 separate initiatives in 17 countries (Osman and Chable 2009).

\section{Box 1}

Farmer variety - a variety developed and managed by farmers, such as a landrace or a historic variety that has been maintained on-farm over many years or a new population created and selected by farmers. Farmer varieties can also include variety mixtures that are grown and harvested together over many years instead of re-constituted each year (see (Bocci et al. 2010) for a detailed description).

Historic variety - a variety, usually a relatively homogeneous selection made within existing landraces or in the early stages of formal plant breeding programmes that was once on a variety registration list but is no longer registered.

Landrace - while there is no one definition for this concept, in general, it is a population of a crop species that has been maintained by farmers in a locality over a sufficiently long period of time so that it develops stable local adaptation. Camacho Villa et al. (2005) proposed a consensus definition based on a review of the literature, which we adopt for the purposes of this article: "A landrace is a dynamic population (s) of a cultivated plant that has a historical origin, a distinct identity and lacks formal crop improvement, as well as often being genetically diverse, locally adapted and associated with traditional farming systems."

Modern variety - a variety resulting from a formal (professional) plant breeding programme, registered under a distinct name and satisfying the criteria of distinctiveness, uniformity and stability as defined by regulations during the variety registration process.

Note: The distinction between historic and modern varieties may also be made on the basis of the date of registration, with varieties released before 1950 considered historic and varieties released after 1950 (when the use of synthetic fertilisers and pesticides became common in breeding programmes) considered modern, and this is more useful in areas that do not have a history of official variety registration.

Varietal mixture - a mixture of distinct plant types, grown and harvested together. Components of the mixture can be landraces, historic varieties or modern varieties. 
On-farm conservation of agricultural biodiversity

Many studies working with farmers in traditional agricultural systems have demonstrated that local seed selection and management practices are key to the development of local adaptation while maintaining genetic diversity in cultivated species. This diversity is maintained through the ongoing action of evolutionary processes within crop populations while human selection maintains traits that are important for agronomic performance and end-use quality (Almekinders et al. 2000; Berthaud et al. 2001; Elias et al. 2001; Louette et al. 1997; Smith et al. 2001). The effectiveness of such a system for in situ conservation depends on the number of populations and the local selection pressures affecting each population as these populations function as a metapopulation, a concept first proposed in an ecological context by Levins (Levins 1970). Contrasted selection pressures will preserve the greatest level of diversity at the metapopulation level, even if each population loses a portion of its initial diversity in the process of selection for local adaptation (Enjalbert et al. 1999; Goldringer et al. 2001a, b, 2006; Lavigne et al. 2001; Paillard et al. 2000; Porcher et al. 2004).

While a strategy of in situ conservation could be pursued at a national or international level through the use of populations grown on research stations, this approach is limited in terms of the number of sites available and the resources that can be dedicated to maintaining appropriate population sizes and management practices. Therefore, most formal systems of conservation are primarily ex situ genebanks. In ex situ conservation, an effort is made to maintain the characteristics of a crop variety sample that were present when it was collected from the field, without continued evolution during regeneration cycles. In contrast, in situ conservation conserves the processes that create and maintain the genetic diversity of populations, rather than a particular sample of genetic diversity. Adaptive genes from landraces and related populations are recognized as important but underutilized for crop improvement (Finckh 2008; Rodriguez et al. 2008; Newton et al. 2010). A seed exchange network among farmers which maintains evolving populations of landraces and other heterogeneous varieties may be a more effective in situ strategy for conserving and giving value to genetic diversity, complementary to ex situ approaches, and with the dual goals of conserving the adaptive potential of crop species and developing well-adapted farmer varieties for organic and low-input agriculture.

\section{Developing locally adapted varieties}

One of the benefits attributed to farmer varieties is their ability to develop local adaptation by responding to evolutionary forces in divergent environmental conditions. This local adaptation leads to stability over time within each location. Annicchiarico (2001) provides an overview of considerations and analytical tools to use when breeding for stability and adaptation. In particular, he points to the importance of distinguishing between repeatable interactions between genotypes and locations, which can be used to develop locally adapted varieties, and non-repeatable year-to-year variation, which should be minimized through the development of temporally stable varieties. Reliability of performance over years is often just as important to farmers as high yields and is certainly more relevant to individual farms than the performance of the variety across a wide range of locations. The exploitation of genotype by environment interactions $(\mathrm{G} \times \mathrm{E})$ through decentralized selection and participatory breeding has been proposed as a solution to developing locally adapted varieties for organic and low-input systems (Ceccarelli and Grando 2007; Desclaux et al. 2008; Ceccarelli 1996; Desclaux and Hédont 2006; Dawson et al. 2008; Lammerts van Bueren et al. 2008; Murphy et al. 2005).

In addition to the importance of genetic diversity to buffer against environmental stresses over time, the variety-by-environment interactions (or $\mathrm{G} \times \mathrm{E}$ ) are an important phenomenon to understand when developing varieties for diverse growing conditions. Interactions occur when the relative responses of varieties to changing environmental conditions differ. Crossover interactions occur when there are significant changes in variety rankings for a certain trait, such as yield, over environments, so that the best variety under one set of conditions is not the best variety under a different set of conditions. In these situations, it is preferable to take advantage of $\mathrm{G} \times \mathrm{E}$ interactions by identifying different varieties that have superior performance in specific environments rather than trying to avoid $\mathrm{G} \times \mathrm{E}$ by selecting varieties with average performance over a broad range of environments, as is done in most conventional breeding programmes (Desclaux 2005; Ceccarelli 1996). 
European context for on-farm conservation and development of farmer varieties

In the European Union (EU), to be commercialised a variety has to be registered in the European catalogue and meet evaluation criteria including being distinct, uniform and stable (DUS) (UPOV 1991; European Commission 2003; European Council 1966, 2002) (see Box 2). This means that the majority of registered varieties are genetically homogeneous, consisting of identical individuals. Because registered varieties are often very similar genetically, with many of the same parental varieties, there is also a danger of losing the diversity of genetic material that was historically conserved in situ by farmers, which is complementary to the diversity conserved in genebanks or research institutes (Demeulenaere et al. 2008). Further regulations for variety registration vary by country but usually include "value for cultivation and use" standards that measure agronomic performance in conventional systems. Most modern varieties are developed for high-input conventional cropping systems. Multi-site testing in conventional environments favours varieties with low spatial $\mathrm{G} \times \mathrm{E}$, meaning that they are adapted to a broad range of geographic locations but only after the environments have been made more similar with the use of input (Ceccarelli 1996). Many farmers using organic and low-input methods are unable to find a variety in the catalogue that is adapted to their agricultural environment.

The interest among organic farmers in Europe in growing landraces, historic varieties and more recently developed farmer varieties is in part due to this lack of adapted varieties in the official catalogue. The EU seed regulations described above prohibit the sale or exchange of these types of varieties as seed for planting because they do not comply with the European criteria for registration. As a result of increasing interest among farmers and recognition of the importance of genetic diversity for future variety development, the European Union has adopted new legislation on "conservation varieties" (see Box 2) (European Commission 2008).

\section{Box 2}

\section{EU variety catalogue registration requirements}

Varieties submitted for registration must meet three requirements: distinctiveness, uniformity and stability (DUS criteria). Crop species should also meet criteria of value for cultivation and use (VCU). Those requirements are assessed by the evaluation of quantitative or qualitative morphological and phenotypical criteria (descriptors). The evaluation for those requirements has to be done for at least two independent plant growth cycles and in multiple locations.

DUS (distinctiveness, uniformity and stability):

- Distinctiveness: Distinctiveness is established if the combination the different descriptors evaluated differs from those of other varieties already registered. "The distinctness is assessed using the $t$-test least significant difference, the difference between two varieties is clear if it occurs with the same sign at the $1 \%$ significance level or less $(p<0.01)$ in two consecutive or two out of three growing cycles"

- Uniformity: All the plants of a registered variety should be the same. "Uniformity is assessed by visual observation and the detection of off-types." Depending of the type of plants observed and on the characteristic observed, the rate of off-types allowed can vary.

- Stability: the characteristics of a variety should be the same over space (in all the test locations) and time (all the years when the variety is tested). "A candidate will be considered to be sufficiently stable when there is no evidence to indicate that it lacks uniformity. Seed samples of further submissions included in any test must show the same expression of characteristics as the material originally supplied (CPVO 2009)."

\section{VCU: value for cultivation and use}

VCU tests evaluate agronomic and technological characteristics such as yield and protein levels. A new variety should perform better (over space and time) for at least one characteristic than varieties already registered.

\section{Conservation varieties:}

The concept of conservation varieties was created in order to classify "old varieties" because such varieties do not meet the criteria of uniformity as established for modern varieties. As defined in the EU Commission Directive 2008/62/EC (2008), conservation varieties must be linked to a "region of origin" where they have been cultivated for a certain period. They must also be threatened by genetic erosion and "present an interest for the conservation of plant genetic resources."

The regulation stipulates that "seed of a conservation variety may only be produced in the region of origin" and there are restrictions of quantities marketed: "the quantity of seed marketed does not exceed $0,5 \%$ of the seed of the same species used in that Member State in one growing season, or a quantity necessary to sow 100 ha, whichever is the greater quantity."

In addition to these restrictions, the varieties listed as conservation varieties must pass modified (less strict) DUS tests, for example, a tolerance of $10 \%$ off-types instead of $1 \%$, but do not have to pass VCU tests.

This legislation recognizes the importance of conserving the genetic diversity represented by landraces and historic varieties by allowing them to be registered as conservation varieties and grown, sold and exchanged as such. However, the legislation sets 
a limited geographic area-the "region of origin"and proportion of the land cultivated within that area allowed to be planted to each conservation variety. It also sets registration requirements for these varieties that are similar to the distinctiveness, uniformity and stability requirements of standard catalogue registration, but exempts them from value for cultivation and use standards used for conventional testing. While this legislative framework is proposed as a solution to the conservation of genetic diversity and would authorize the use of varieties that met the modified registration criteria, it is unclear how many of the farmer varieties currently in use in the organic community (by farmers who save their own seed and market grain products) would fit these guidelines.

\section{Goals of the study}

The work reported in this paper was part of a project supported by the European Commission to assess the potential of on-farm selection and conservation to protect genetic diversity in cultivated species. The larger project had three main goals in studying the potential of farmers varieties in Europe: (a) to assess their ability to meet the needs of low-input and organic farmers, (b) to understand their importance for the conservation of genetic diversity, and (c) to identify characteristics of these varieties in relation to farmers' practices for the implementation of the new European legislation on conservation varieties. The specific goals of the work presented here were to:

(a) Assess the appropriateness of DUS criteria when applied to conservation varieties. Measurements based on those used for the DUS evaluation were taken on multiple farmer varieties and modern varieties at on-farm trials.

(b) Test the relevance of "region of origin" restrictions for the conservation of genetic diversity and evolutionary potential. Farmer varieties were grown in their region of origin and on participating farms outside the region of origin to assess local adaptation and spatial stability.

(c) Make the scientific and legislative processes more participatory by working directly with organic farmers to evaluate varieties which are of interest under diverse environmental conditions. Farmers and farmer associations were involved from the beginning in the project conception, design, management and interpretation of results.

Several farmer varieties already being cultivated under low-input (non-certified organic) and certified organic management conditions were studied, through a network of on-farm trials in Italy, the Netherlands and France. Participating farmers contributed bread wheat varieties that they are currently growing for local markets. The trials developed were exploratory in nature and designed to evaluate different types of farmer varieties rather than to identify superior cultivars for organic agriculture. This study allows us to assess the range of variation within and among farmer varieties and modern varieties under organic farming conditions and the appropriateness of the proposed regulatory framework for conservation varieties. We discuss the implications of the results for seed and variety regulation, particularly with regard to regulatory scenarios that would encourage the development of varieties for organic agriculture and the involvement of farmers in variety innovation.

\section{Materials and methods}

\section{On-farm trials}

The experiment took place in the 2006-2007 growing season and was conducted on six farms, one in the Netherlands, two in Italy and three in France. The conditions of the trials were very diverse because of the geographical locations and differences in farming systems and agronomic practices (see Table 1). Soil type and fertility management, the presence of livestock or not in the farming system, crop rotations, tillage and weed management, precipitation, yearly average and extreme temperatures, all contributed to differences in trial environments and conditions that would have contributed to shape the farmer varieties evaluated in this experiment. All farms used organic management, and farmers were interested in and experienced in cultivating historic and landrace varieties of bread wheat. Each site was managed as the farmer would normally manage bread wheat on their farm and all the varieties within each location were given identical management. This was considered the best way to realistically evaluate the performance of 
different varieties on contrasting farms. Italian trials were in the mountains of the Abruzzi region (TDS, central Italy) and the plains of the Veneto region (GC, NE Italy). The French trials were in the Mediterranean region (HF, southern France), in Aquitaine (JFB, SW France) and in the Loire valley (FM, NW France). The Dutch trial (PVI, central Netherlands) was situated in Flevoland on a polder, which is arable land formed by draining fields.

\section{Varieties}

Each farmer participating in the experiment chose a variety that he had been growing for several years and wanted to contribute to the project. The eight varieties chosen represent different types of wheat varieties (landraces, mixtures and historic varieties) primarily grown and selected by farmers and are referred to as farmer varieties, as stated before. Two modern varieties were included for comparison (one is the reference for organic agriculture in France and the other one was selected for conventional agriculture). Variety characteristics and regions of origin are listed in Table 2. The following abbreviations are used for variety names:

$\begin{array}{ll}\text { AU } & \text { Aubusson } \\ \text { PI } & \text { Piave } \\ \text { RB } & \text { Rouge de Bordeaux } \\ \text { RN } & \text { Renan } \\ \text { RD } & \text { Redon } \\ \text { HL } & \text { Haute Loire } \\ \text { TO } & \text { Touselles } \\ \text { SO } & \text { Solina } \\ \text { ZW } & \text { Zeeuwse Witte } \\ \text { ZH } & \text { Zonnehoeve }\end{array}$

The varieties represent a broad range of diversity in terms of their genetic structures and phenotypic characteristics. Samples of the same seed lot of each variety were sent to each farmer participating in the experiment, so that each farmer grew plots of each variety in a RCBD with two replicates and $10-\mathrm{m}^{2}$ plots. Each farmer provided the researchers with their normal seeding rate in grains per square meter, and researchers calculated the weight of grain to be sown in a $10-\mathrm{m}^{2}$ plot based on this rate and the thousand-kernel weight of each sample. Each variety within a location had the same sowing method, date and density and the same 
Table 2 Description of varieties used in the experiment

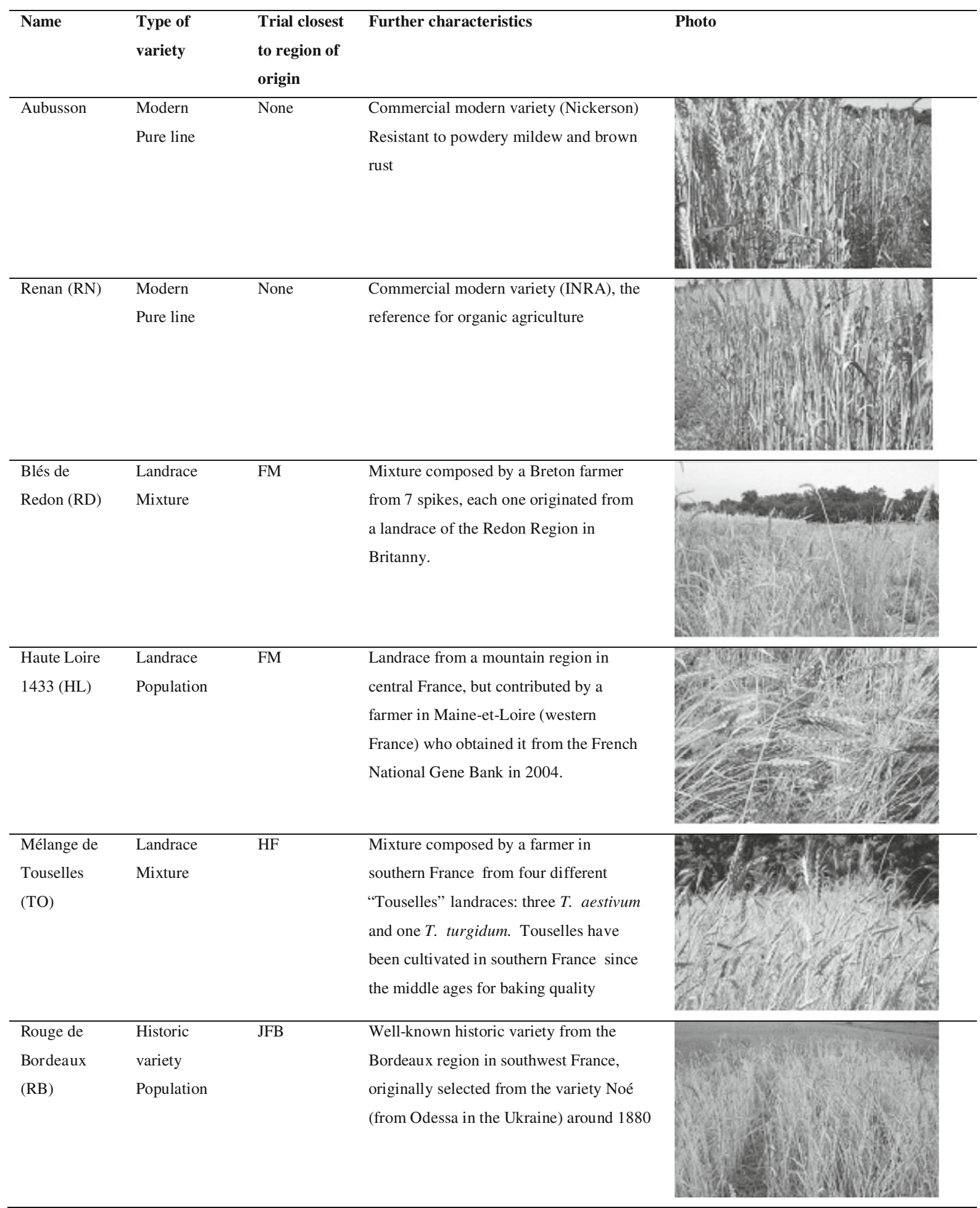


Table 2 (continued)

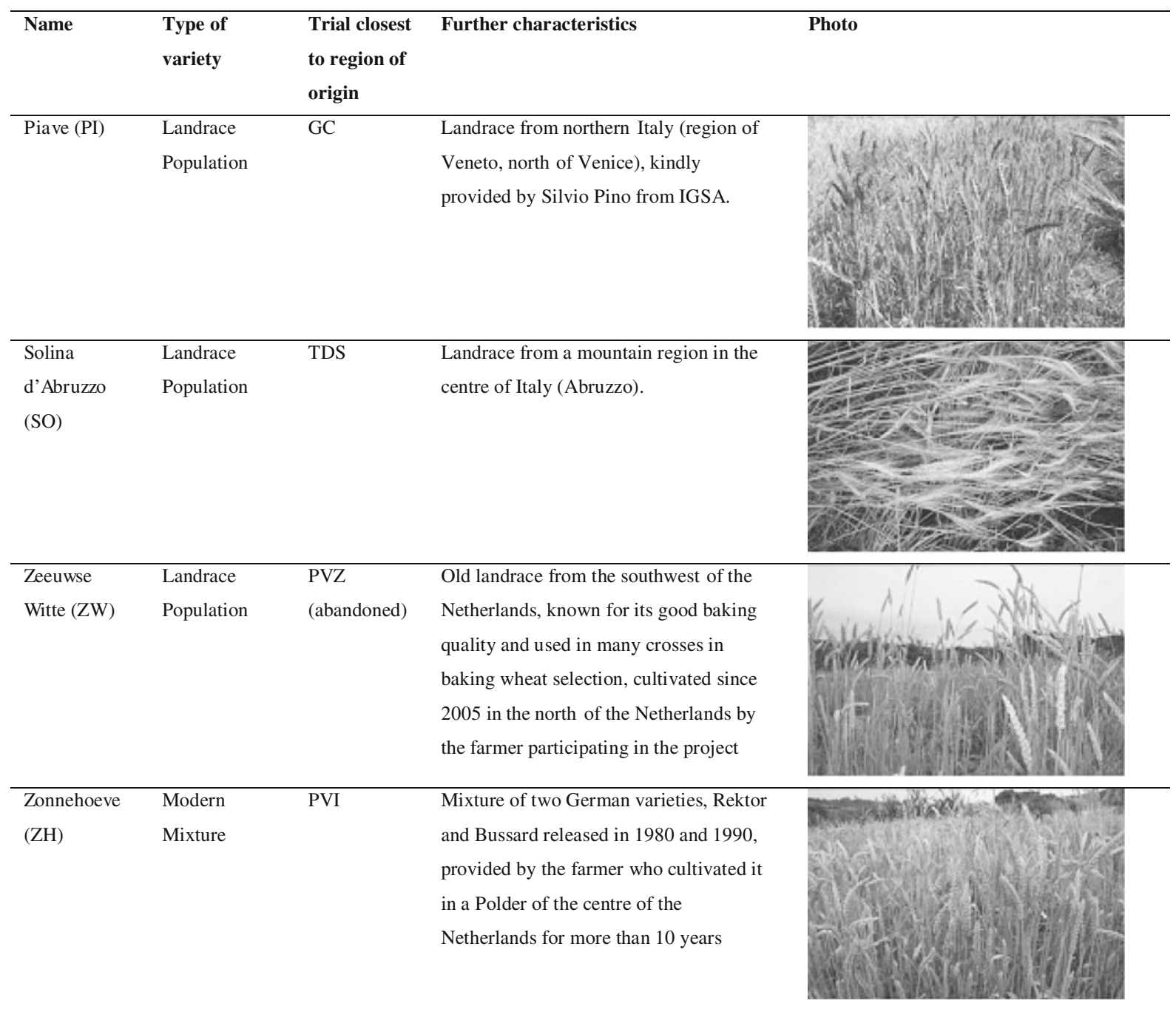

IGSA Istituto di Genetica e Sperimentazione Agronomica di Vicenza, Italy

weed management practices. Some farmers planted the two replicates of each variety consecutively so they were considered a single replicate in the analysis.

Plant measurements

Quantitative measurements were taken twice, once during the growing season, where vegetative traits were measured, and once after harvest, when a sample of spikes was collected and measured. The choice of traits to measure was based on International Union for the Protection of New Varieties of Plants descriptors and was designed to assess whether the use of the criteria of distinctiveness, uniformity and stability for farmer varieties to be registered as conservation varieties is appropriate, but included also traits of interest to farmers, including the distance between spikelets on each spike and the distance between the spike and the flag leaf, which they consider important for quality and disease resistance because looser spikes and a larger distance between the leaves and spikes keep the spike drier and help prevent infection of the spike by diseases migrating from the foliage. 
Traits measured and abbreviations:

SL Spike length (centimetres)

GW Grain weight per spike (grams)

KN Kernel number per spike

TKW Thousand-kernel weight (grams), 1,000× GW/KN

$\mathrm{SpD} \quad$ Spikelet distance (centimetres), average distance between spikelets=spike length/ number of spikelets

$\mathrm{PH} \quad$ Plant height (centimetres), from the soil to the top of the spike, awns excluded

LLSD Last (flag) leaf to spike distance (centimetres), the length of the stem from its insertion in the flag leaf sheaf to the base of the spike

At all on-farm trials, 25 spikes from individual plants for each replication were harvested at maturity, bagged and measured at the research station, for a total of 50 spikes per variety for each on-farm trial. For the variety Piave, birds ate most of the grain before maturity at two out of six sites so it was not always possible to harvest 25 spikes for each plot. Plants were chosen at random from the plot, avoiding the outside rows, and one spike per plant was harvested. At sites where the two reps of each variety were planted end-to-end, the 50 spikes counted as a single replication. Phenotypic descriptors of spike and yield components included: SL, GW (per spike), KN (per spike), TKW and SpD (average distance between spikelets). Compact spikes have a lower $\mathrm{SpD}$ and loose spikes have a higher SpD. In addition to the traits measured on spikes at maturity, it was possible to collect vegetative measurements at some of the sites. These were $\mathrm{PH}$ at trials GC and TDS and LLSD at trials TDS, PVI and FM, taken on one tiller/spike for 25 individual plants per replication, after flowering during the period of grain filling.

Statistical analysis

ANOVA was performed in SAS (SAS Institute, Inc., Cary, NC, USA) using proc GLM with varieties considered fixed effects and locations considered random. Random interaction effects of variety $\times$ location were tested for locations GC, HF, PVI and TDS, where there were two replications. Least squared (LS) means were calculated for all varieties using the model without interactions for pairwise comparisons using Tukey's multiple comparison procedure. Proc GLM was also used to calculate LS means for each variety by location to compare changes in rank among locations.

Intra-varietal variability across and within locations

The overall coefficient of variation (CV) was broken into the variation of the LS means for varieties across environments and the remaining $\mathrm{CV}$ of each variety within each environment. The variation across environments allows us to assess the quantitative impact of $\mathrm{G} \times \mathrm{E}$ interactions for each trait. The withinlocation $\mathrm{CV}$ assesses the variability of each variety with respect to its mean value for that trait. Withinlocation variability of each variety was also assessed using the standardized residuals of the ANOVA to compare the absolute levels of variability. The standardized residuals give a measure of variability after accounting for environmental and genotypic effects, which includes the variation among individuals independent of the varietal mean values and experimental error. We assume that the experimental error was of the same order from one plot to the next based on visual assessment of the trials and the relatively low CV across environments. Therefore, the standardized residual variation allowed us to compare the amount of intra-varietal variation among individual plants. Stability parameters based on varietal means for each trait at all locations were calculated using the methods of Finlay and Wilkinson (1963), Shukla (1972) and Nassar and Hühn (1987) with a SAS programme published by Hussein et al. (2000). Cluster analysis based on the $\mathrm{G} \times \mathrm{E}$ interactions weighted by the square root of Wrick's ecovalences (the sum of the squared $\mathrm{G} \times \mathrm{E}$ interaction effects for each variety (Becker and Leon 1988)) was also performed using the same SAS programme. Cluster analysis using $\mathrm{G} \times \mathrm{E}$ interactions is used to identify groups of varieties that behave similarly over environments in terms of the interactions, even if trait mean values are different. The traits $\mathrm{PH}$ and LLSD and the variety Piave were not included in the stability analysis because of the limited number of locations with data, and for the analysis of GW and TKW, the variety RB and the location GC were not included due to missing data. 


\section{Results}

From the ANOVA, there were significant effects $(p<$ 0.01 ) of the environment and the variety for every trait. $\mathrm{G} \times \mathrm{E}$ interactions were significant when these could be tested. The main effects of environment, variety, $\mathrm{G} \times \mathrm{E}$ interactions and variability within environments and varieties are discussed in the sections below.

\section{Environmental effects}

The locations FM and GC were intermediate for most traits, with low KN. The CVs of location HF were particularly high, and this could be linked to strong weed pressure that caused unequal plant development and significant competition during grain formation and filling. At location JFB, the spikes had high SL, low $\mathrm{SpD}$ and high KN but low TKW. Spikes at location PVI could be described as highly productive. They had the lowest SL and SpD, with high GW and TKW. This location shows low CVs perhaps due to a high sowing density and fertile soil. Spike trait values at TDS were generally low, and this was probably linked with poor soil fertility.

\section{Varietal effects}

Pairwise comparisons of LS means showed significant differences among varieties. Table 3 presents variety means and groupings across locations. The two modern varieties, Renan and Aubusson, were always significantly different from each other. However, they were closest in rank and had significantly shorter PH and LLSD and higher GW compared to the other varieties. While Renan had a longer SL, greater TKW and lower KN, Aubusson had a shorter $\mathrm{SL}$, greater KN and lower TKW.

Piave appeared quite productive in the sites where spike data could be collected. It had the highest values for GW, KN and SL; high TKW and moderate values for SpD, LLSD and PH. Rouge de Bordeaux had the highest PH and LLSD; high GW, TKW and SL and intermediate $\mathrm{KN}$ and $\mathrm{SpD}$. This is probably due to the preferences of the farmer, who selects tall plants with long SL and LLSD. Touselles also had high PH, long LLSD and SL and a fairly high KN.

Haute Loire, Redon and Solina had very similar behaviour, with low values for GW and KN. They had
Table 3 Least squares mean values for each variety and trait and groupings of varieties resulting from Tukey's procedure for all pairwise comparisons among varieties

\begin{tabular}{|c|c|c|c|}
\hline Trait & Variety & LS mean & Group \\
\hline \multirow[t]{10}{*}{ Grain weight (g) } & PI & 1.94 & A \\
\hline & $\mathrm{RN}$ & 1.63 & $\mathrm{~B}$ \\
\hline & $\mathrm{AU}$ & 1.45 & $\mathrm{C}$ \\
\hline & $\mathrm{RB}$ & 1.36 & $\mathrm{DC}$ \\
\hline & $\mathrm{TO}$ & 1.31 & $\mathrm{D}$ \\
\hline & $\mathrm{ZH}$ & 1.27 & $\mathrm{D}$ \\
\hline & ZW & 1.24 & $\mathrm{DE}$ \\
\hline & HL & 1.12 & $\mathrm{EF}$ \\
\hline & $\mathrm{RD}$ & 1.08 & $\mathrm{~F}$ \\
\hline & SO & 0.82 & G \\
\hline \multirow[t]{10}{*}{ Number of kernels per spike } & PI & 43.85 & A \\
\hline & $\mathrm{AU}$ & 41.30 & A \\
\hline & $\mathrm{ZH}$ & 35.82 & $\mathrm{~B}$ \\
\hline & $\mathrm{TO}$ & 34.15 & $\mathrm{BC}$ \\
\hline & $\mathrm{RN}$ & 33.65 & $\mathrm{BC}$ \\
\hline & $\mathrm{RB}$ & 32.99 & $\mathrm{BC}$ \\
\hline & ZW & 31.75 & $\mathrm{C}$ \\
\hline & $\mathrm{RD}$ & 26.90 & $\mathrm{D}$ \\
\hline & HL & 25.48 & $\mathrm{D}$ \\
\hline & $\mathrm{SO}$ & 20.89 & $\mathrm{E}$ \\
\hline \multirow[t]{10}{*}{ Distance between spikelets $(\mathrm{cm})$} & $\mathrm{SO}$ & 0.61 & A \\
\hline & HL & 0.57 & $\mathrm{~B}$ \\
\hline & $\mathrm{RD}$ & 0.56 & B \\
\hline & $\mathrm{RN}$ & 0.55 & $\mathrm{~B}$ \\
\hline & $\mathrm{RB}$ & 0.53 & $\mathrm{C}$ \\
\hline & PI & 0.50 & $\mathrm{D}$ \\
\hline & ZW & 0.48 & $\mathrm{D}$ \\
\hline & $\mathrm{AU}$ & 0.46 & $\mathrm{E}$ \\
\hline & $\mathrm{TO}$ & 0.46 & $\mathrm{E}$ \\
\hline & $\mathrm{ZH}$ & 0.46 & $\mathrm{E}$ \\
\hline \multirow[t]{10}{*}{ Plant height $(\mathrm{cm})$} & $\mathrm{RD}$ & 135.35 & A \\
\hline & $\mathrm{TO}$ & 132.25 & A \\
\hline & $\mathrm{RB}$ & 130.28 & A \\
\hline & HL & 120.23 & $\mathrm{~B}$ \\
\hline & ZW & 117.79 & B \\
\hline & PI & 116.60 & $\mathrm{~B}$ \\
\hline & $\mathrm{SO}$ & 115.48 & $\mathrm{~B}$ \\
\hline & $\mathrm{ZH}$ & 97.73 & $\mathrm{C}$ \\
\hline & $\mathrm{RN}$ & 72.13 & $\mathrm{D}$ \\
\hline & $\mathrm{AU}$ & 65.18 & $\mathrm{E}$ \\
\hline \multirow[t]{3}{*}{ Thousand-kernel weight (g) } & $\mathrm{RN}$ & 47.15 & A \\
\hline & PI & 42.27 & B \\
\hline & HL & 42.15 & B \\
\hline
\end{tabular}


Table 3 (continued)

\begin{tabular}{|c|c|c|c|}
\hline Trait & Variety & LS mean & Group \\
\hline & $\mathrm{RB}$ & 39.47 & $\mathrm{C}$ \\
\hline & ZW & 38.52 & $\mathrm{C}$ \\
\hline & $\mathrm{RD}$ & 38.39 & $\mathrm{C}$ \\
\hline & $\mathrm{SO}$ & 38.06 & $\mathrm{C}$ \\
\hline & TO & 37.40 & $\mathrm{CD}$ \\
\hline & $\mathrm{AU}$ & 35.79 & $\mathrm{DE}$ \\
\hline & $\mathrm{ZH}$ & 34.88 & $\mathrm{E}$ \\
\hline \multirow[t]{10}{*}{ Spike length (cm) } & $\mathrm{RN}$ & 9.6 & A \\
\hline & PI & 9.6 & A \\
\hline & $\mathrm{RD}$ & 9.4 & $\mathrm{AB}$ \\
\hline & $\mathrm{RB}$ & 9.3 & $\mathrm{AB}$ \\
\hline & ZW & 9.1 & $\mathrm{ABC}$ \\
\hline & $\mathrm{ZH}$ & 9.0 & $\mathrm{C}$ \\
\hline & TO & 8.6 & $\mathrm{D}$ \\
\hline & $\mathrm{AU}$ & 8.5 & $\mathrm{D}$ \\
\hline & SO & 8.3 & $\mathrm{DE}$ \\
\hline & HL & 8.1 & $\mathrm{E}$ \\
\hline \multirow[t]{10}{*}{ Last leaf-spike distance $(\mathrm{cm})$} & $\mathrm{RB}$ & 27.52 & A \\
\hline & TO & 25.83 & $\mathrm{AB}$ \\
\hline & SO & 25.24 & $\mathrm{AB}$ \\
\hline & PI & 23.75 & BC \\
\hline & HL & 23.48 & $\mathrm{BC}$ \\
\hline & ZW & 22.27 & $\mathrm{C}$ \\
\hline & $\mathrm{RD}$ & 21.29 & $\mathrm{C}$ \\
\hline & $\mathrm{ZH}$ & 16.16 & $\mathrm{D}$ \\
\hline & $\mathrm{RN}$ & 8.88 & $\mathrm{E}$ \\
\hline & $\mathrm{AU}$ & 4.13 & $\mathrm{~F}$ \\
\hline
\end{tabular}

Varieties with the same letter do not have significantly different mean values (at $p<0.05$ )

fairly large PH, LLSD and SpD. In many locations, they showed significant lodging before harvest due to their thin stems (especially for Solina and Haute Loire). However, they had moderate values of TKW although Redon was more variable than other varieties for this trait within locations.

The two Dutch varieties, Zeeuwse Witte and Zonnehoeve, had spikes that were phenotypically very similar, while the vegetative growth was quite different. Zeeuwse Witte was fairly tall and more heterogeneous for PH, with long SL and high KN. Zonnehoeve had a shorter and more homogeneous $\mathrm{PH}$ and LLSD than the other farmer varieties, but was still significantly taller than the modern varieties. It had high KN with low SpD and TKW.
$\mathrm{G} \times \mathrm{E}$ interactions and varietal stability

Figure 1 presents variety LS means by location, with locations ordered by increasing overall mean. Crossover $\mathrm{G} \times \mathrm{E}$ interactions are present for all traits. SL appeared to be more influenced by environment effects, while $\mathrm{G} \times \mathrm{E}$ interactions more strongly affected other traits. Aubusson showed strong changes in rank for $\mathrm{KN}$ and SL, while Renan changed rank for GW, KN and SL. For the farmer varieties, Haute Loire had significant changes in rank for SL, Piave for GW and KN, Solina for SL and Zonnehoeve for TKW.

An assessment of varietal stability using the regression of varietal means in each location on environmental means (data not shown) revealed no significant differences in slopes among varieties based on the methods of Eberhart and Russell (1966) and no significant differences from an ideal stable genotype based on Shukla's stability variance or Wricke's ecovalence. Clustering patterns were highly variable depending on the trait, and it was difficult to find similarities among this set of varieties, which indicates that each has a unique response to environmental conditions.

Intra-varietal variability across and within locations

The CV of the LS means for varieties across environments is presented in Fig. 2a, and the remaining CV of each variety within each environment is presented in Fig. 2b. Across environments, the traits fell into two general groups, those that varied considerably, including GW, TKW and KN, and those that were less variable from one environment to another, including SL and $\mathrm{SpD}$. Even for varieties that show significant $\mathrm{G} \times \mathrm{E}$ interactions, the variation in a trait across environments for a certain variety was usually lower than that among plants of the same variety within one location (intraplot variation). The average $\mathrm{CV}$ within trials showed high levels of variation for GW and $\mathrm{KN}$ and moderate levels for TKW and SL. There was very little variation for SpD and $\mathrm{PH}$. Touselles showed higher variability for GW, $\mathrm{KN}$ and SpD, while for LLSD, Aubusson had higher within-site CVs than the farmer varieties. This was probably due to a very small mean value of this trait for Aubusson, so even small variation around this mean led to a large $\mathrm{CV}$.

Standardized residual plots from the ANOVA model illustrate the within-variety variability inde- 
A.

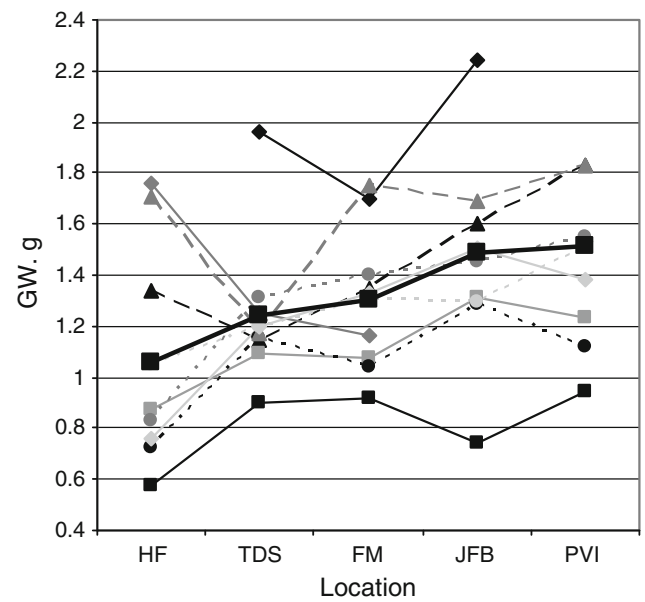

C.

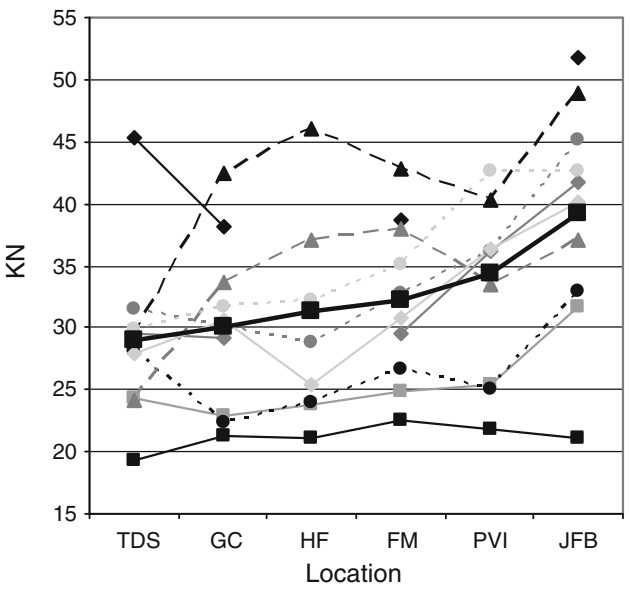

E.

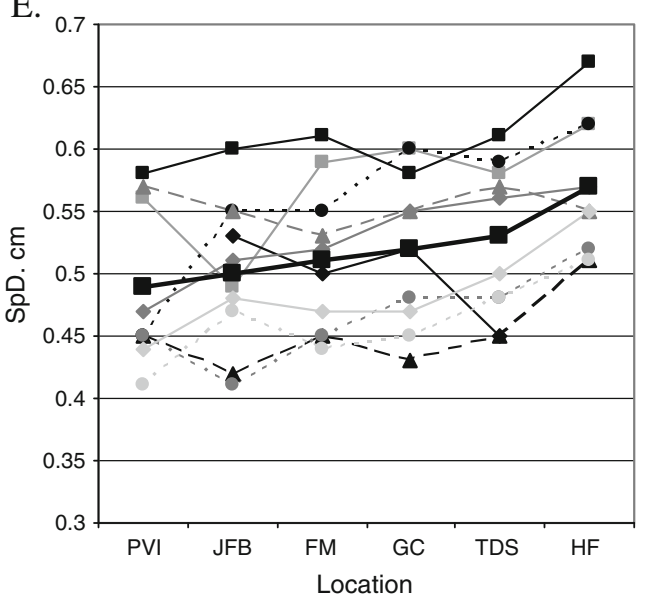

Fig. 1 Least square (LS) mean values (solid black lines), and individual variety means for each trait in each location with locations ordered by increasing LS means for each graph. A
B.

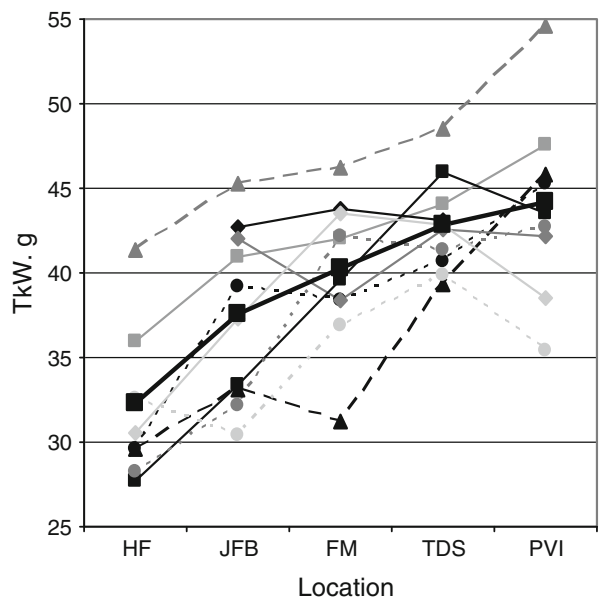

D.
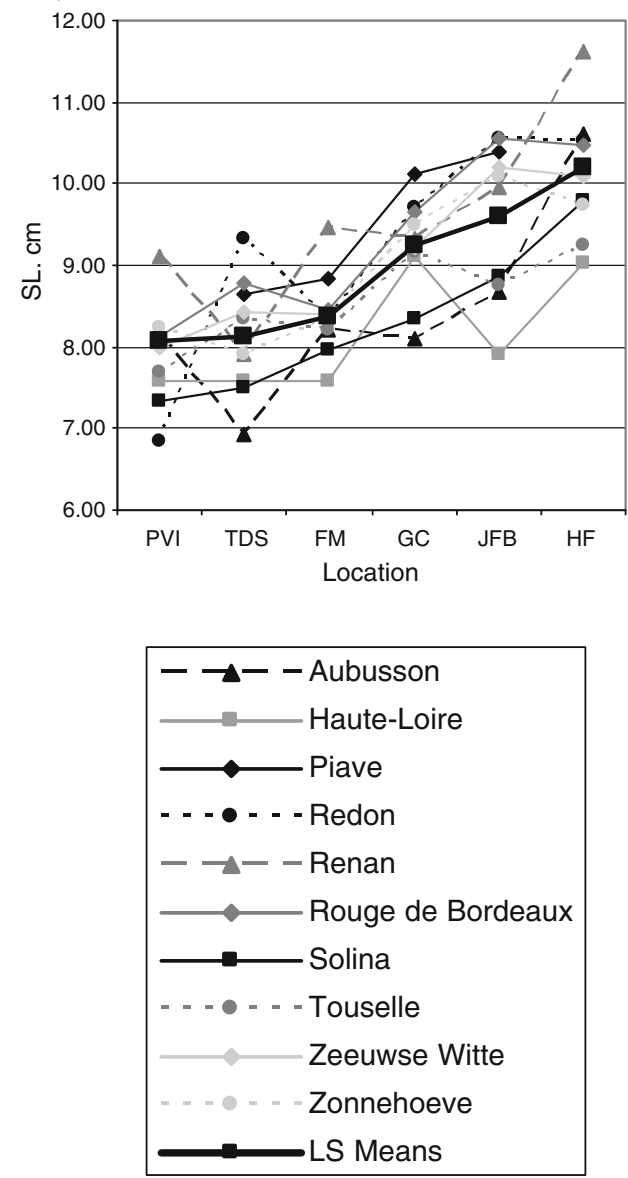

Grain weight $(G W)$, B thousand-kernel weight $(T K W), \mathbf{C}$ kernel number per spike $(K N)$, D spike length $(S L)$, $\mathbf{E}$ distance between spikelets $(S p D)$, F plant height $(P H)$ 


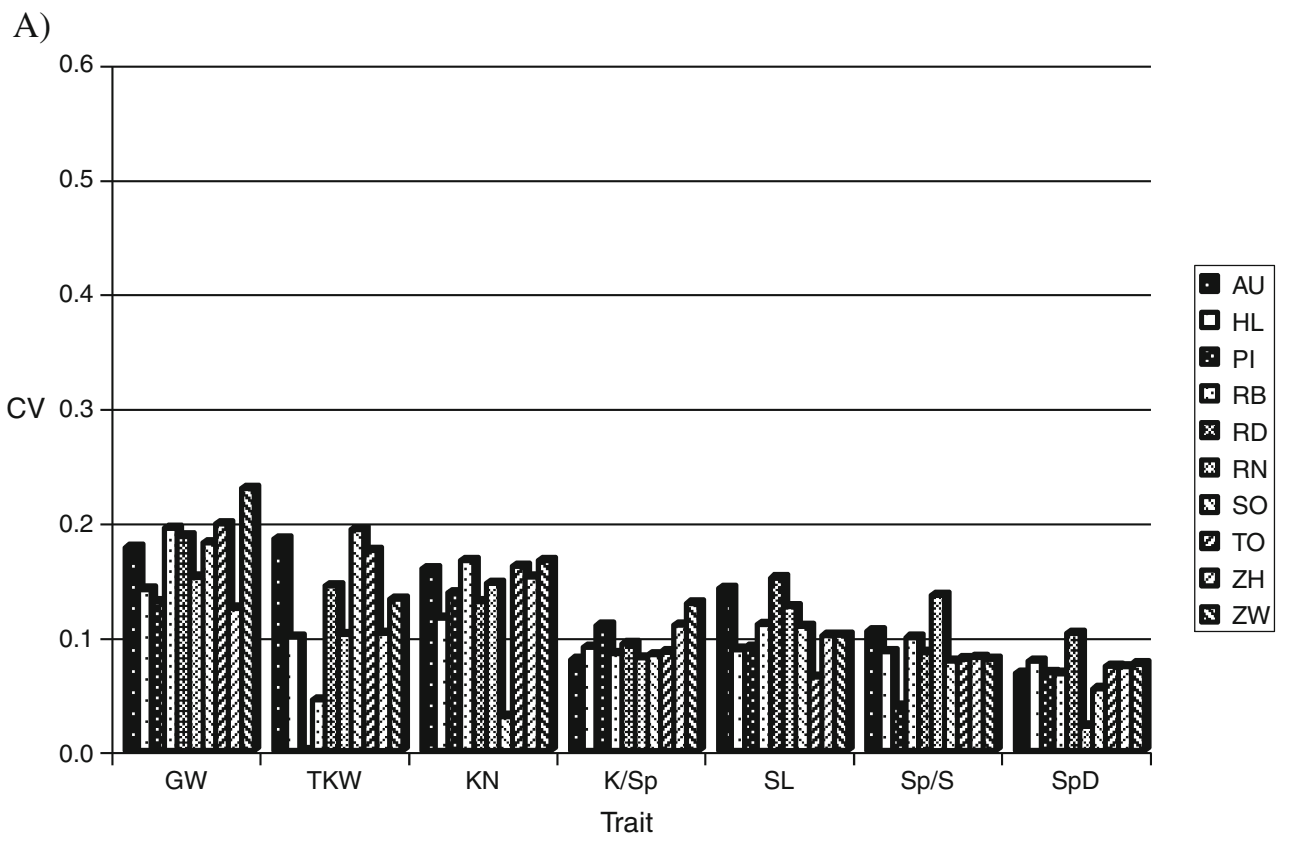

B)

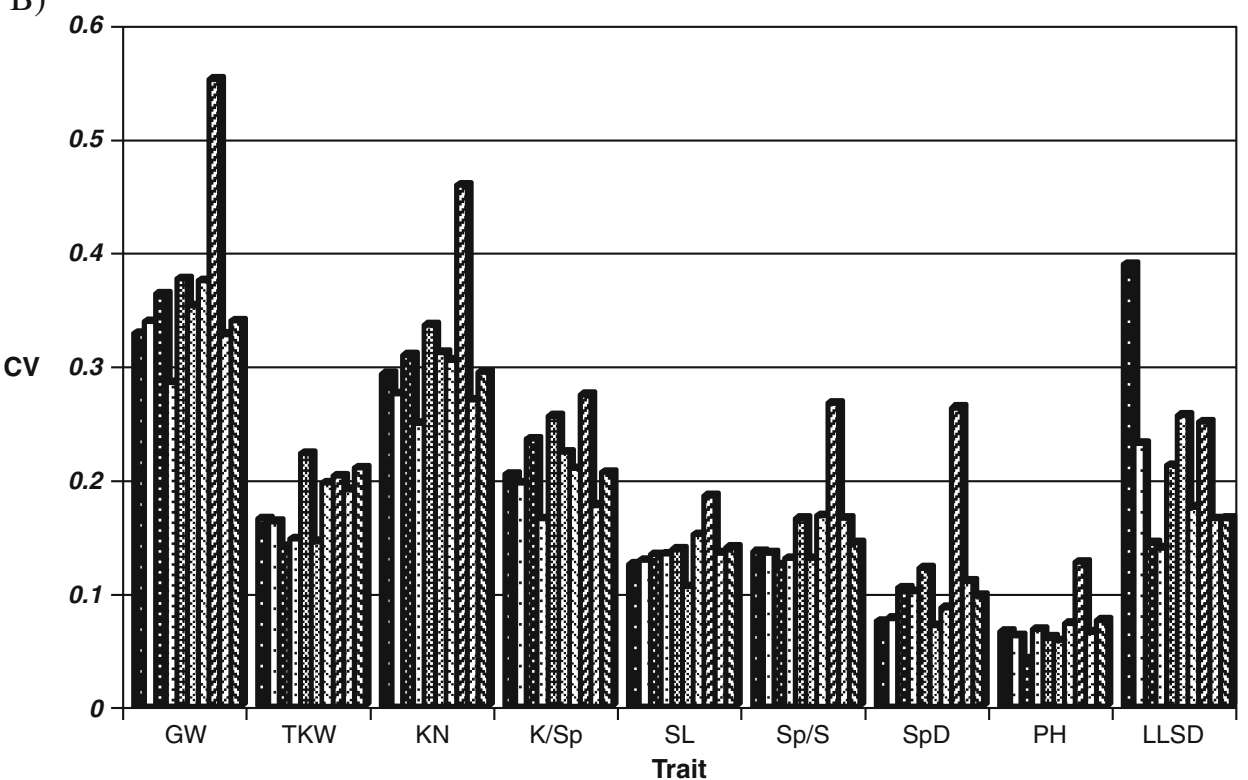

Fig. 2 a Coefficients of variation $(\mathrm{CV})$ for each trait averaged across varieties within each location, b CV for each trait averaged across all locations for each variety

pendent of the trait mean value (Fig. 3). GW and TKW are shown among the traits measured on the spikes; the other traits showed similar patterns of variation. $\mathrm{PH}$ and LLSD are shown based on data from two and three locations, respectively. Renan and Aubusson appeared less variable for PH and LLSD. Renan was also fairly homogeneous for SL and Aubusson was fairly homogeneous for $\mathrm{SpD}$. In contrast, Piave had greater than normal variation within locations for $\mathrm{GW}$ and $\mathrm{KN}$, which could be in part due to its precocity, making it more susceptible to bird damage and shattering. Despite being more variable for SL and $\mathrm{PH}$, Rouge de Bordeaux was less variable than other varieties within locations for other traits. Haute Loire was fairly homogeneous for GW, $\mathrm{KN}$ and SL, but the amount of variation within 
locations for LLSD was higher than for other varieties. Solina was more variable within locations for SL and less variable for GW and TKW. Touselles again stood out for its higher levels of residual variation.

\section{Discussion}

\section{Environmental effects}

The results from this study should be interpreted with some caution because on-farm trials necessitate a balance between the number of replications and the number of varieties that can be tested with limited space and without putting too many demands on farmers' time. We chose to test a greater number of varieties from contrasting regions of origin and to limit replications to two. However, all quantitative measurements are based on 25 individuals per plot, giving us 50 individuals contributing to the LS means of the measured traits for each variety in each location. Trial fields were, in general, visually uniform, and we found more variation among individuals in the same plot than among the plot LS means across environments for the same variety.

We did not find strong specific local adaptation of the farmer varieties to their region of origin but in some cases, varieties had a higher value for some traits when they were grown within their region of origin. For example, RB at JFB had high KN and SL, and $\mathrm{ZH}$ (and to a lesser extent $\mathrm{ZW}$ ) at PVI had high $\mathrm{GW}, \mathrm{KN}$ and LLSD. It is interesting that each variety does not necessarily have the highest values for spike productivity traits such as GW and $\mathrm{KN}$ in its region of origin. These measures of yield components on a spike-by-spike basis may not necessarily be the same as those selected on a whole-field level by yearly harvest and replanting of farmer varieties. It may also mean that the traits we identify as important for agronomic performance are not necessarily the best measures of specific adaptation. Furthermore, it underscores the importance of farmer experimentation with many different varieties as they may find farmer varieties or modern varieties from other regions that are of interest on their farms.

Productivity is also not necessarily the only trait the farmers are looking for in their choice of preferred varieties, as there are subjective criteria that contribute to the choice of some varieties which were not investigated in this study (such as the preference for certain visual aspects like spike colour or shape, the ease of working with the variety or its taste). Because farmers involved in the study market their grain directly to small-scale millers and bakers or are themselves millers or bakers, quality is of great importance and farmers have stated that while yield is important, the quality of their varieties for artisanal bread making must be consistently high. While industrial millers and bakers are concerned about intravarietal diversity because they feel this may lead to inconsistent quality in a highly standardized process, the farmers in this project have observed that increasing diversity in the field tends to buffer quality aspects and that they can adapt their milling and baking to account for small changes in composition from year to year. This empirical evidence is supported by a study of wheat mixtures in 19 lowinput environments over 2 years by de Vallavieille-Pope et al. (2004), who found that four-way varietal mixtures had equivalent yields and bread-making quality to the best pure varieties, with increased spatial and temporal stability. The miller involved in the project did not have objections to the use of mixtures and continued working with the participating farmers after the end of the study. Most of the participating farmers in our study grow heterogeneous varieties and varietal mixtures in their production fields, and while this was not part of the current study, it is important to point out that none of the farmers had quality concerns with the varieties contributed to the project. In fact, these varieties were often contributed because they possessed high baking quality for artisanal bread making.

\section{Varietal effects}

There is some phenotypic evidence of the selection history of these varieties. Certain traits may be related to farmer or breeder practices as much as to the region of origin. The two modern varieties (Aubusson and Renan) presented a parallel pattern of responses over the environments, especially for KN, SL and LLSD and to a lesser extent for GW and SpD. Renan was selected for broad adaptation to low-input systems and was one of the most productive varieties across locations on a per-plant basis, although its short stature made it susceptible to weed competition at the plot level. Haute Loire and Solina were phenotypically very similar, with thin stems and small spikes and, together with Redon, they often had similar responses in terms of means and variances 
A. Grain Weight per Spike

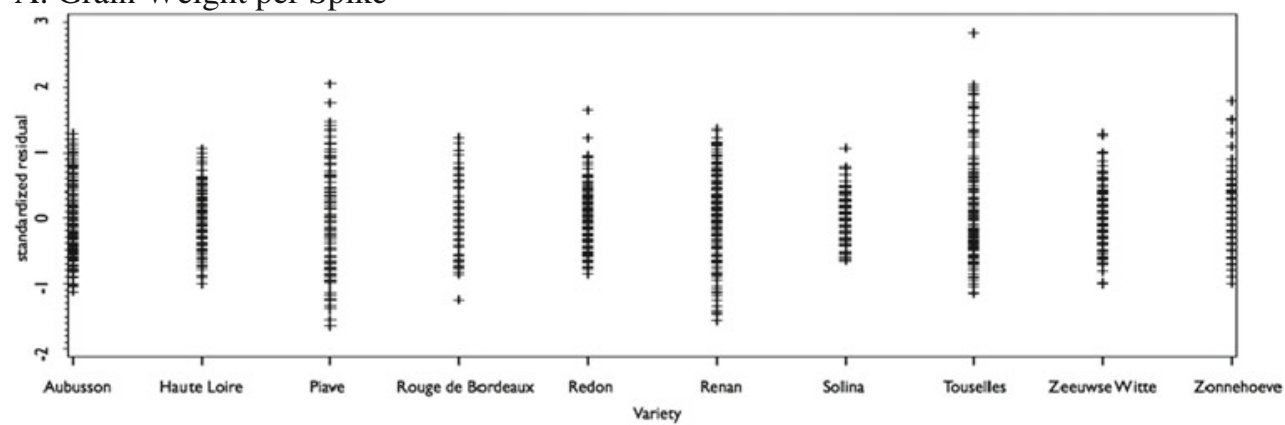

B. Thousand Kernel Weight

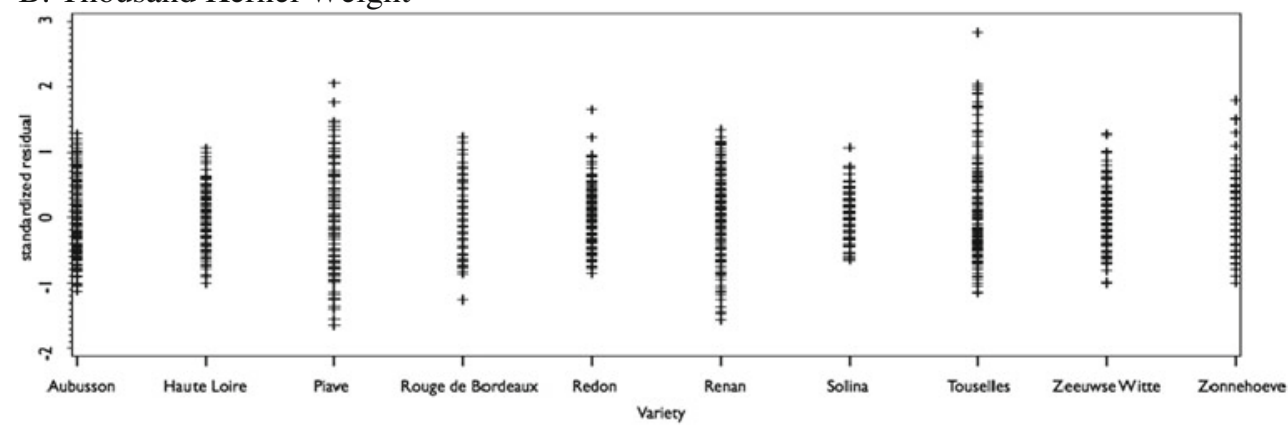

C. Plant Height

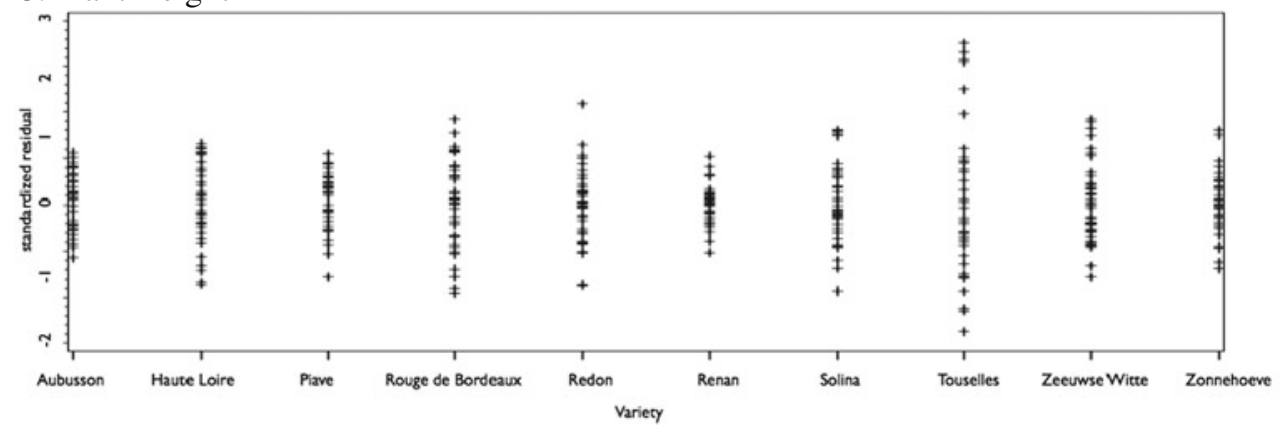

D. Last-Leaf-Spike-Distance

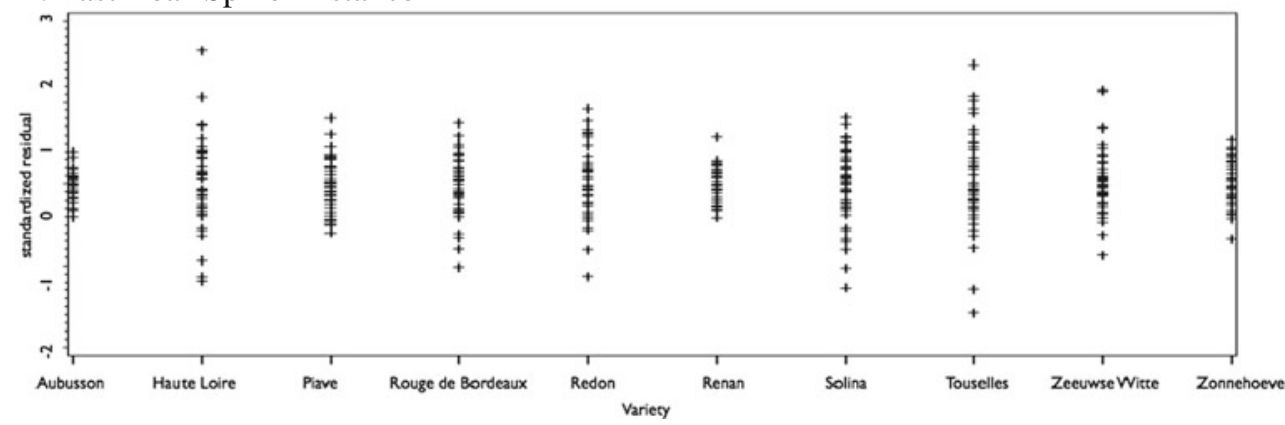

Fig. 3 Standardized (studentized) residuals of each variety from the ANOVA analysis including $\mathrm{G} \times \mathrm{E}$ interactions as a measure of intra-varietal phenotypic variation. The standardized residuals include both experimental error and variation due to the individuals. Experimental error is assumed to be constant across the experiments 
over the environments. These varieties appeared poorly adapted to several of the environments tested in this study, especially to conditions with fertile soils where they were sensitive to lodging. Haute Loire, Solina and Redon are the oldest landraces in the trials based on the period when they were first recorded as being in cultivation. However, Haute Loire and Redon were obtained from the French National Gene Bank quite recently so they may suffer from a lack of adaptation to the current climate and conditions. Solina has been continuously grown by farmers in the mountains of the Abruzzo region of Italy under marginal conditions in terms of soil and climate (very low fertility, extreme temperatures and drought) and may be very specifically adapted to those conditions and not well adapted to more fertile or diverse conditions.

\section{Homogeneity}

While modern varieties could be expected to be genetically uniform, we see from the analysis that they often had significant phenotypic variability within locations, and conversely, while farmer varieties are genetically diverse, they often showed surprising phenotypic uniformity. In most cases, it was not possible to statistically distinguish modern varieties from farmer varieties based on their level of intra-population variability for the traits measured. Because intra-varietal variation estimated on the basis of the $\mathrm{CV}$ is influenced by the means, it was difficult to compare modern varieties with farmer varieties for PH and LLSD based on the CV because their mean values were so different. When intra-varietal variation based on standardized residuals was considered instead, it appeared that for PH and LLSD, Aubusson and Renan had less residual variation. Renan also had more uniform spike length, but for other traits, farmer varieties often showed equal or less standardized residual variation than modern varieties.

Visually, plots of modern varieties appeared more homogeneous, primarily for PH, LLSD and SL, which made the identification of potential off-types easier than within landrace plots. As modern varieties are generally made uniform through the elimination of off-types in the field or selection of 'typical' heads and plants, it is not unexpected that they are the most uniform for characteristics that are easily assessed visually. Quantitatively, however, in terms of traits assessed on spikes post-harvest, there was still a considerable amount of variation.

Although modern varieties must pass strict criteria for homogeneity before being released, it appears that under organic and low-input conditions, characterized by heterogeneous environments, modern varieties may be just as variable phenotypically as some farmer varieties for certain traits, and farmer varieties often had unexpectedly low residual variability. Touselles was an exception in that it often had the highest levels of residual variation. This was expected as it is an interspecies mixture of four distinct landraces, all named Touselle but phenotypically different than one another, especially the Triticum turgidum component of the mixture. Redon, while also a mixture of seven different landraces named Redon, does not have the same level of phenotypic variation.

Stability

There were no significant differences in parametric measures of phenotypic stability among varieties in this study, but it is clear from Fig. 1 that there were large crossover $\mathrm{G} \times \mathrm{E}$ interactions for most traits, and there were significant changes in rank for varieties across environments. If these varieties were to be used for plant breeding, selection for broad adaptation across this range of environments may be less effective than selection within environments for some traits. Regression analysis was developed to identify varieties with broad adaptation across the locations under study, and stable varieties were defined as those having a slope near one, preferably with mean values superior to the environmental mean. Shukla's stability variance is calculated so that genotypes are stable if their stability variance is equivalent to the variation within environments, i.e. there is no variation across environments and is independent of the trait mean, genetic and error variances (Shukla 1972). Therefore, it is not surprising that there were no differences among varieties for stability parameter as higher levels of phenotypic variation was observed within environments than across environments for almost all traits for all varieties. The ecovalence combines differences in slopes and deviations from the linear regression into one measure of stability, where varieties are stable if they have a slope near one and low deviations from the regression. Again, it is not surprising that there were no differences among varieties, as varieties showed non- 
linear $\mathrm{G} \times \mathrm{E}$ and high levels of intra-varietal variation within environments.

Even though putatively bred for high spatial stability as measured by the types of stability statistics we used here, the modern varieties did not differ significantly from farmer varieties for spatial stability in this study. The study presented in this article was not able to address the temporal stability of farmer varieties due to the short time frame, but ongoing research is exploring this aspect of heterogeneous varieties, as stability is a key reason farmers choose to grow this type of variety. Stability over years is often just as important as high values for yield related traits, and this stability may be achieved through the flexibility of yield components depending on environmental conditions in any particular year or across locations. Lin and Binns (1988) suggests two steps to breeding cultivars with high stability: (a) identify cultivars with an optimal range of responses for the environments under consideration using regression approaches, with each variety $\times$ location mean averaged over years and (b) then find varieties with small within-location variance (mean square within location) using years within location as an indicator of the unpredictable environmental variation that the cultivar will need to be able to buffer in that location. Farmers involved in the project say that a new variety they receive from another farmer or a genebank generally takes 4 to 5 years to develop temporal stability on their farms, so it is difficult to evaluate temporal stability for these varieties outside their region of origin in the time frame of most research projects. An ongoing project is studying these varieties for quantitative traits over several years in each of these locations, to observe the evolution of the varieties due to natural selection/adaptation. While the study presented in this article was not a participatory plant breeding project, the bases for many participatory plant breeding projects lie in the use of the genetic diversity present in farmers varieties.

\section{Conclusion}

While the directive on conservation varieties is an improvement over existing standards, it does not include the range of farmer varieties currently of interest in organic systems and may not be adequate for some types of on-farm conservation and plant breeding activities, especially those conducted by established farmers' seed groups, which rely on a broad seed exchange network to maintain and enhance diversity and agronomic performance. This study showed great diversity and differences in response patterns among farmer varieties and modern varieties when exposed to highly divergent organic production environments. There were highly significant differences among varieties and high levels of intra-varietal variability. In these conditions, contrary to what is found in conventional variety registration trials, the level of residual variation within varieties was not always less in the two modern varieties when compared to farmer varieties. In addition, farmer varieties often had high values for traits related to productivity outside their region of origin and suggests the importance of farmer experimentation with diverse material in order to find well-adapted materials. Our results also question the belief that farmer varieties have developed very specific adaptation that is useful only in a limited region. Because of the diverse nature of organic farming systems, it may be difficult to predict which varieties will do best in a certain location. Farmer experimentation on their own farm is probably the best way to identify those varieties and to promote the conservation of historic varieties and landraces. Increasing farmer access to farmer varieties from other regions and allowing farmer experimentation and on-farm variety selection will require changes in the regulatory framework for variety registration to accommodate more diverse farmer varieties, including those that currently exist and those developed through on-farm breeding. The on-farm conservation of farmer varieties can be an objective in itself if farmers find a variety that meets their needs, or it can be the first step in a participatory plant breeding programme. Both strategies benefit from the ability to evaluate and use the widest range of genetic diversity available.

Acknowledgements This work was funded by a Specific Targeted Research Project of the European Commission 6th Framework Program Priority 8.1 SSP: Opportunities for farm seed conservation, breeding and production Proposal/Contract no.: SSP-CT-2006-044345. Thanks to Nathalie Galic for technical support and advice and to Thomas Levillain for project coordination. We would especially like to thank the farmers who have participated in the project: Jean François Berthellot, Vincent Chesneau, Giandomenico Cortiana, Tonino Del Santis, Henri Ferté, Piet Van Ijzendoorn, Florent Mercier and Piet van Zanten. 


\section{References}

Almekinders CJM, Jongerden J (2002) On visions and new approaches: case studies of organisational forms in organic plant breeding and seed production. Working paper, Technology and Agrarian Development, Wageningen University and Research Center Publications, The Netherlands

Almekinders CJM, de Boef W, Engels J (2000) Synthesis between crop conservation and development. In: Almekinders C, de Boef W (eds) Encouraging diversity: the conservation and development of plant genetic resources. Intermediate Technology, London, pp 330-338

Altieri MA (1999) The ecological role of biodiversity in agroecosystems. Agric, Ecosyst Environ 74:19-31

Annicchiarico P (2001) Defining adaptation strategies and yield-stability targets in breeding programmes. Chapter 24. In: Kang MS (ed) Quantitative genetics, genomic and plant breeding. CABI, New York, pp 365-383

Becker HC, Leon J (1988) Stability analysis in plant breeding. Plant Breed 101:1-23

Berthaud J, Clément JC, Emperaire L, Louette D, Pinton F, Sanou J et al (2001) The role of local level gene flow in enhancing and maintaining genetic diversity. In: Cooper HD, Spillane C, Hodgkin T (eds) Broadening the genetic base of crop production. IPGRI/FAO, Rome, pp 81-103

Bocci R, Chable V, Kastler G, Louwaars NP (2010) Set of recommendations on farm conservation strategy, the role of innovative market mechanisms, legislative framework for landraces, conservation varieties and amateur varieties in Europe. European Commission-Sixth Framework Programme

Camacho Villa T, Maxted N, Scholten M, Ford-Lloyd B (2005) Defining and identifying crop landraces. Plant Genet Resour Charact Util 3:373-384

Ceccarelli S (1996) Positive interpretation of genotype by environment interactions in relation to sustainability and biodiversity. In: Cooper M, Hammer GL (eds) Plant adaptation and crop improvement. CAB International, New York, pp 467-486

Ceccarelli S, Grando S (2007) Decentralized participatory plant breeding: an example of demand driven research. Euphytica 155:349-360

Ceccarelli S, Grando S, Bailey E, Amri A, El-Felah M, Nassif F, Rezgui S, Yahyaoui A (2001) Farmer participation in barley breeding in Syria, Morocco and Tunisia. Euphytica 122:521-536

CPVO, Community Plant Variety Office (2009) Protocol for distinctness, uniformity and stability tests, Triticum aestivum L., wheat. CPOV-TG/003/4 rev., available online http://www.cpvo.europa.eu. Verified 24 Nov 2010

Dawson JC, Murphy KM, Jones SS (2008) Decentralized selection and participatory approaches in plant breeding for low-input systems. Euphytica 160:143-154

de Vallavieille-Pope C, Fraj MB, Mille B, Meynard J-M (2004) Les associations de variétés: accroître la biodiversité pour mieux maitriser les maladies. Doss de l'environnement de l'INRA 30:101-109

Demeulenaere E, Bonneuil C, Balfourier F, Basson A, Berthellot J-F, Chesneau V, Ferté H, Galic N, Kastler G, Koenig J, Mercier F, Payement J, Pommart A, Ronot B,
Rousselle Y, Supiot N, Zaharia H, Goldringer I (2008) Étude des complémentarités entre gestion dynamique à la ferme et gestion statique en collection : cas de la variété de blé Rouge de Bordeaux. Les Actes du BRG 7, Strasbourg, 13-15 Oct 2008.

Desclaux D (2005) Participatory plant breeding methods for organic cereals. In: Lammerts Van Bueren ET, Ostergard H (eds) Proceedings of the COST SUSVAR/ECO-PB workshop on organic plant breeding strategies and the use of molecular markers. Driebergen (NK), 17-19 January 2005, pp 17-23

Desclaux D, Hédont M (eds) (2006) Proceedings of the ECOPB workshop on participatory plant breeding: relevance for organic agriculture? Workshop held in Domaine de la Besse, France, 11-13 June 2006. European Consortium for Organic Plant Breeding, Institut Technique de l'Agriculture Biologique, Paris

Desclaux D, Nolot JM, Chiffoleau Y, Leclerc EGC (2008) Changes in the concept of genotype $\times$ environment interactions to fit agriculture diversification and decentralized participatory plant breeding: pluridisciplinary point of view. Euphytica 163:533-546

Eberhart SA, Russell WA (1966) Stability parameters for comparing varieties. Crop Sci 6:36-40

Elias M, McKey D, Panaud O, Anstett MC, Robert T (2001) Traditional management of cassava morphological and genetic diversity by the Makushi Amerindians (Guyana, South America): perspectives for on-farm conservation of crop genetic resources. Euphytica 120:143-157

Enjalbert J, Goldringer I, Paillard S, Brabant P (1999) Molecular markers to study genetic drift and selection in wheat populations. J Exp Bot 50:283-290

European Council (1966) Council Directive 66/402/EEC of 14 June 1966 on the marketing of cereal seed (last modification in 2009). OJ 125, 11 Jul 1966, pp 2309-2319. Available online http://eur-lex.europa.eu. Verified 21 Apr 2011

European Council (2002) Council Directive 2002/53/EC of 13 June 2002 on the common catalogue of varieties of agricultural plant species. OJ L 193, 20 Jul 2002, pp 111. Available online http://eur-lex.europa.eu. Verified 21 Apr 2011

European Commission (2003) Commission Directive 2003/90/ EC of 6 October 2003 setting out implementing measures for the purposes of Article 7 of Council Directive 2002/53/ EC as regards the characteristics to be covered as a minimum by the examination and the minimum conditions for examining certain varieties of agricultural plant species (text with EEA relevance). OJ L 254, 8 Oct 2003, pp 710. Available online http://eur-lex.europa.eu. Verified 21 Apr 2011

European Commission (2008) Commission Directive 2008/62/ EC of 20 June 2008 providing for certain derogations for acceptance of agricultural landraces and varieties which are naturally adapted to the local and regional conditions and threatened by genetic erosion and for marketing of seed and seed potatoes of those landraces and varieties (text with EEA relevance). Available online http://eur-lex. europa.eu. Verified 21 Apr 2011

Finckh MR (2008) Integration of breeding and technology into diversification strategies for disease control in modern agriculture. Eur J Plant Pathol 121:399-409 
Finckh MR, Wolfe MS (2006) Diversification strategies. In: Cooke BM, Gareth Jones D, Kaye B (eds) The epidemiology of plant disease, 2nd edn. Springer, the Netherlands

Finlay KW, Wilkinson GN (1963) The analysis of adaptation in a plant breeding programme. Aust J Agric Res 14:742754

Goldringer I, Enjalbert J, David J, Paillard S, Pham JL, Brabant P (2001a) Dynamic management of genetic resources: a 13 year experiment on wheat. In: Cooper HD, Spillane C, Hodgkin $\mathrm{T}$ (eds) Broadening the genetic base of crop production. IPGRI/FAO, Rome, pp 245-260

Goldringer I, Enjalbert J, Raquin A, Brabant P (2001b) Strong selection in wheat populations during ten generations of dynamic management. Genet Sel Evol 33(Suppl 1):441463

Goldringer I, Prouin C, Rousset M, Galic N, Bonnin I (2006) Rapid differentiation of experimental populations of wheat for heading time in response to local climatic conditions. Ann Bot 98(4):805-817

Hussein MA, Bjornstad A, Aastveit AH (2000) SASG X ESTAB: a SAS program for computing genotype $\times$ environment stability statistics. Agron J 92:454-459

Lammerts van Bueren ET, Ostergard H, Goldringer I, Scolten O (2008) Plant breeding for organic and sustainable, lowinput agriculture: dealing with genotype-environment interactions. Euphytica 163:321-322

Lavigne C, Reboud X, Lefranc M, Porcher E, Roux F et al (2001) Evolution of genetic diversity in metapopulations: Arabidopsis thaliana as an experimental model. Genet Sel Evol 33:S399-S423

Levins R (1970) Extinction. In: Gesternhaber M (ed) Some mathematical problems in biology. American Mathematical Society, Providence, pp 77-107

Lin CS, Binns MR (1988) A method of analysing cultivar $\times$ location $\times$ year experiments: a new stability parameter. Theor Appl Genet 76:425-430

Louette D, Charrier A, Berthaud J (1997) In situ conservation of maize in Mexico: genetic diversity and maize seed management in a traditional community. Econ Bot 51:20-38

Murphy KM, Lammer D, Lyon SR, Carter B, Jones SS (2005) Breeding for organic and low-input farming systems: an evolutionary-participatory breeding method for inbred cereal grains. Renew Agric Food Syst 20(1):48-55

Murphy KM, Campbell KG, Lyon SR, Jones SS (2007) Evidence of varietal adaptation to organic farming systems. Field Crops Res 102:172-177
Nassar R, Hühn M (1987) Studies on estimation of phenotypic stability: tests of significance for nonparametric measures of phenotypic stability. Biometrics 43:45-53

Newton AC, Akar T, Baresel JP, Bebeli PJ, Bettencourt E, Bladenopoulos KV, Czembor JH, Fasoula DA, Katsiotis A, Koutis K, Koutsika-Sotiriou M, Kovacs G, Larsson H, Pinheiro de Carvalho MAA, Rubiales D, Russell J, Dos Santos TMM, Vaz Patto MC (2010) Cereal landraces for sustainable agriculture. A review. Agron Sustain Dev 30:237-269

Osman A, Chable V (2009) Inventory of initiatives on seeds of landraces in Europe. J Agric Environ Int Dev 103(1/2):95130

Paillard S, Goldringer I, Enjalbert J, Trottet M, David J, de Vallavielle-Pope C, Brabant P (2000) Evolution of resistance against powdery mildew in winter wheat populations conducted under dynamic management. I. Is specific seedling resistance selected? Theor Appl Genet 101:457462

Porcher E, Giraud T, Goldringer I, Lavigne C (2004) Experimental demonstration of a causal relationship between heterogeneity of selection and genetic differentiation in quantitative traits. Evolution 58(7):1434-1445

Rodriguez M, Rau D, Papa R, Attene G (2008) Genotype by environment interactions in barley (Hordeum vulgare L.): different responses of landraces, recombinant inbred lines and varieties to Mediterranean environment. Euphytica 163:231-247

Shukla GK (1972) Some statistical aspects of partitioning genotype-environmental components of variability. Heredity 28:237-245

Smith ME, Castillo GF, Gomez F (2001) Participatory plant breeding with maize in Mexico and Honduras. Euphytica 122(3):551-565

UPOV (International Union for the Protection of New Varieties of Plants) (1991) Act of 1991 International Convention for the Protection of New Varieties of Plants of December 2, 1961 as revised at Geneva on November 10, 1972 and on October 23, 1978 and on March 19, 1991. UPOV, Geneva

Wolfe MS (2000) Crop strength through diversity. Nature 406:681-682

Wolfe MS, Baresel JP, Desclaux D, Goldringer I, Hoad S, Kovacs G, Löschenberger F, Miedaner T, Østergard H, Lammerts van Bueren ET (2008) Developments in breeding cereals for organic agriculture. Euphytica 163: 323-346 